\title{
THE INFLUENCE OF INDIVIDUAL KNOWLEDGE AND WORK TEAM DEVELOPMENT TO THE MANUFACTURING COMPANY PERFORMANCE OF IN EAST JAVA
}

\author{
Widjojo Suprapto \\ Faculty of Economics, Petra Christian University, Surabaya, Indonesia \\ Corresponding author; Email: joe.suprapto@petra.ac.id
}

\begin{abstract}
Individual knowledge is the fundamental human capital to contribute to the greatness of the company. The personal capability and competence should be dispersed to other individuals within the organization to form a work team that is reliable and motivated so that each individual can easily do the work communication. As a result, it gives an impact on the flexibility of working people and eventually can improve the company performance. The data are collected by questionnaires that are distributed to 90 industrial practitioners, with the 86 completed data that can be further processed. The result of this study states that the individual knowledge influences strongly on the development of the competent work team, and enhances the collaboration and communication process. The development of the work teams in the company affects the collaboration, communication, and effectiveness of the work teams. Finally, the cooperation and communication in the work place and the effectiveness of the work teams together improve the company performance.
\end{abstract}

Keywords: Individual knowledge, work team development, work flexibility effectiveness, and company performance.

\section{Introduction}

A research by Quang and Vuong (2002) states that the best human resources management practices are obtained from the effective process of organizational management in planning, organizing, and controlling the available components to reach the organizational objectives. Meanwhile, a research by Lewis, Frenmouw, Del Ben, and Farr (2001) reveals that the proper matching between the leadership style and the real operational condition in a company will surrender an effective working process, therefore, each organization is affected by the management styles to each individual, working group, and company performance. The effectiveness of an organization is obtained through the task and responsibility management by distributing the job descriptions or working standards, building good rapports between upper and lower management levels, and creating good rapports among workers and their communities, and finally building worker commitments to the organization (Quang \& Vuong, 2002). Good rapports can be achieved from sharing knowledge and communication to collaborate among employees so that they can equip each other to create new knowledge (Hoof \& Deridder, 2004).

The management has to utilize all resources effectively and efficiently. The individual effectiveness revealed by Hoof and Deridder (2004) is supported by a research by Cabrera and Cabrera (2005) which states the sharing of individual competency and expertise to others in order to maximize the company values. A research of Osterloh and Frey (2000) also mentions that the sharing knowledge among individuals and departments is a crucial process that needs management attentions. Another research conducted by Liao and Cuang (2004) reveals that individual knowledge is related to the effectiveness in communication and relation commitment through sharing knowledge. One employee can communicate and relate to other employees so that each employee contributes to others based on their expertise, and, in the long term, each employee can form a skillful work team (Wasjo \& Farad, 2005).

Individual learning orientation is the first step in sharing knowledge and creating collaboration among employees. To stimulate perceptively the stream of knowledge, an organization can implement several steps: first of all, individual level, which is communicated among employees individually; then, each individual introduces and communicates to the whole organization members to create good teamwork; and finally the organization sets the performance standards. There are two ways to achieving the organizational performance: boosting the individual performance so that the organizational performance increases and encouraging the learning orientation 
individually to achieve the effective working process so that the organizational performance increases (Magnini, 2008).

The first way is to achieve the organizational performance through the individual employees, who are in the lower levels, by setting organizational goals and targets directly to increase the performance. The second way is aimed to the middle and top management level by increasing their expertise and new competences to create innovation which in the end will give positive impacts to the organizational performance. For the learning process orientation, each individual need to conduct some evaluation processes by comparing the results obtained and the objectives set during the planning stage (Wang \& Nicholas, 2005). Spencer and Spencer (2003) reveal that the concept of competency has developed into different meanings, yet is still found in many literature reviews in dealing with jobs and organizations, and contains five characteristics. The two characteristics are about knowledge or information possessed by employees in a specific field, and about experexpertise or the ability to perform some mental or physical tasks; both of them are considered as the foundation of a competency which can be developed and trained through exercises and experiences. The next three characteristics are about motivation, attitudes, and self concept, which all are more difficult to develop and train.

Disputes among employees often happen, especially in dealing with other coworkers and with their supervisors. In order to build strong teamwork, the employees have to overcome the disputes. It is also strongly related to the evaluation conducted by the human resources department to each employee, in terms of his work ability, attitude, value, opinion, and experience; and this evaluatio $\mathrm{n}$ can also determine the future path of each employee and the reward and punishment for each personnel in an organization (Ho, 2007). A research by Emmerik and Sanders (2005) finds that the individual success in work place can be achieved through building communication and relation among other fellows so they can work efficiently and effectively with the commitment from each organization members. In evaluating satisfaction and work effectiveness, Maley and Kramar (2007) state that the regular and intense communication with the supervisors brings positive impacts to the employee work motivation, besides the fair evaluation and feedback.

Individual work efficiency and effectiveness can be achieved when the employees can easily adapt to the surroundings, including the new tasks and working environment, which is often called as the individual working flexibility (Parris, Vickers, \& Wilkes, 2005). This concept of flexible workers includes the following aspects: the available working time, the expectation working place, and the attitude and career development in a company. Flexibility is divided into two types: the flexibility to the work approaches which is offered by the organization to the employees and the flexibility to the work arrangement so that the employees can accomplish their task better and useful for the organization (Johnson, 2004). The employee flexibility is closely related to an expertise development in doing a new innovation process for a certain task to create a more effective and efficient process, which will surrender a good working team (Parris et al., 2005). This employee flexibility can be obtained by rotating each employee to different working stations so each employee is accustomed to do the different tasks according to the needs of the company (Banerjee, 2003). The management will always arrange the employee flexibility to reach the target and to increase the competitive advantage of the company.

Consider it as a team. A work team is a group of workers with certain skills and commitment to reach the same targets and goals. Team members who work together are called a teamwork, and this teamwork represents a unity of value and suggests every member to listen, respond positively, support, and appreciate to each others about the needs and success of every member (Hu, Horng, \& Sun, 2009). The unity of value will help the team excel and motivate the emergence of individual and organizational achievements, and will also determine the relationship between the team members and the management in setting up its role to the company performance.

\section{The Research Hypothesis}

A research conducted by Liao and Cuang (2004) reveals that individual knowledge determined by agreement and consistent factors has influenced the commitment to communicate and collaborate through sharing knowledge among employees. According to Wasjo and Farad (2005), each single person can communicate and collaborate with others and enable that person to contribute the expertise through sharing knowledge which later on will construct a skillful work team. The research by Ardichvili, Maurer, and Li (2006) states that the sharing knowledge from individual by forming the Community of Practice (COP) will enlighten others to solve the problems. Sharing knowledge among members and among departments is a crucial process, if not managed properly, and even can hinder the formation 
of solid teams. A research by Harvey and Napier (2004) suggests the individual competency to have influences on managerial competency and global competitive advantage as most expatriate managers utilize their time properly in building the work communication and collaboration until the formation of work flexibility in their organization. A research conducted in ICT Company in Thailand proves that the sharing knowledge from an individual to other employees brings positive influences on learning process of the staff behavior, and the performance of the company (Dechawatanapaisal, 2005).

$H_{l}$ : The improvement of the competent individual knowledge will increase the development of work team in a company.

$\mathrm{H}_{2}$ : The improvement of the competent individual knowledge will increase the communication and collaboration in a company.

A research by Bhatnagar (2008) reveals that the formation of cross functional work teams (such as work team from marketing, production, warehouse, accounting, and others) and the formation of other specialized groups that need the expertise of cross functional teamwork become more effective and bring impacts to the increasing company performance. Basu, Hartono, Lederer and Sethi (2002) say that the development of work teams together with the management commitment will improve the benefit and performance of a company. Staff training and development in ICT Company in Thailand has positive influences on the staff behavior learning process and the company performance (Dechawatanapaisal, 2005).

$\mathrm{H}_{3}$ : The continuous improvement of solid work team development can increase the employee communication and collaboration in the working area within a company.

Individual knowledge with an internal motivation factor to communicate, collaborate, and coordinate can drive positive impacts to sharing knowledge and working efficiency. Bhatnagar (2008) wrote that the formation of cross functional work teams and the formation of specialized task forces that rely on cross functional teams can increase the company performance. However, a research by Harvey and Napier (2004) states that collaboration and learning process do not bring any impacts to the company"s global competitive advantage because the teamwork of the expatriate managers is not functioning effectively. The knowledge, expertise, competency, and experience of the managers in an effective work team will contribute to the company through optimizing the organizational assets, and finally to the effectiveness of the organization (Hosie, Forster, \& Sevastos, 2004).

$\mathrm{H}_{4}$ : The effectiveness of work team in a company can increase the company performance.

$H_{5}$ : The effective communication and collaboration in a company can improve the company performance.

Based on the previous research review, the research framework can be described as in Figure 1.

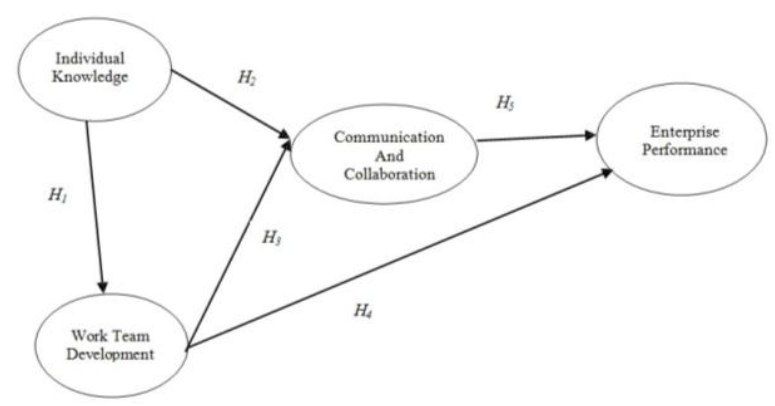

Figure 1. Research Framework

\section{Research Method}

This research is going to describe the reciprocal relationship between variables through the hypothesis testing. Data collection technique is using questionnaires that are distributed to employees to obtain some descriptive information about the individual knowledge, personal value, and informant description. The questionnaire is using a closed end that is the questions made in such a way so the respondents are limited in giving answers to some alternatives only or to one answer only. The variables are about individual knowledge, work team development, communication and collaboration, and company performance. The sampling technique is using convenience sampling that is distributing the questionnaires to companies willing to participate (Cooper, 2008). The samples are collected from the human resources departments which have conducted the job rotations for at least one year. The distributed questionnaires are one hundred questionnaires to manufacturing companies in East Java, and the data are collected from 90 respondents. From the collected data, there are four incomplete questionnaires; therefore only 86 questionnaires are further processed. To test the hypothesis, Partial Least Square (PLS) is used to examine the influence of one variable to others.

\section{Result and Discussion}

The respondent characteristics based on their job positions are presented in Table 1. For this research, 
the respondents are those who understand about the employee rotation in the company and mostly are the personnel in the human resources department and the operational department.

Table 1

Respondent Characteristics Based on Their Positions

\begin{tabular}{lcc}
\hline \multicolumn{1}{c}{ Structural positions } & Numbers & Percentage \\
\hline Manager & 13 & $15 \%$ \\
Assistant Manager & 20 & $23 \%$ \\
Supervisor & 27 & $31 \%$ \\
Staff & 26 & $30 \%$ \\
\hline Total & 86 & $100 \%$ \\
\hline
\end{tabular}

The total percentage of respondents who understand the employee rotations is $70 \%$, which consists of the supervisors, assistant mangers, and managers. This concludes that the leaders of the companies have done their role properly in managing the human resources to reach the efficiency and effectiveness. The leaders can directly interact with employees as they have the authority and responsibility.

The structural model or inner model is evaluated by using Goodness of Fit Test to see the percentage of variants. It is to observe the $R$-square for latent dependent construct using -square test and to observe the value of the path coefficient. The stability of this estimation is evaluated using $t$-statistic test, which is obtained through the bootstrapping procedure. The structural model is evaluated using dependent variable $R$-square with similar interpretation of regression. $Q$-square predictive relevance for construct model is used to measure the observed value of the model and also the estimation of its parameter. The value of $Q$-square is higher than zero (0) indicates the predictive relevance of the structural model (Table 2).

Table 2

The Result of $R$-Square in PLS Output

\begin{tabular}{lc}
\hline & $\boldsymbol{R}$-square \\
\hline Knowledge & \\
Development & 0.378 \\
Collaboration & 0.336 \\
Performance & 0.501 \\
\hline
\end{tabular}

The PLS output results show the values of $R$ square higher than zero (0) for the dependent variables as seen on Table 2 . The dependent variable of work team development gets the value of 0.378 ; the value of communication and collaboration is 0.336 , and the value of company performance is 0.501 . Meanwhile, the value of $Q$-square is 0.4305 , which is higher than zero $(0)$, and indicates the model having predictive relevance. The causal relationship built for this hypothesis model needs to be tested. The results of the hypothesis testing can be seen in Table 3 .

Table 3

The Result for Inner Weight from PLS Output

\begin{tabular}{lcccc}
\hline \multicolumn{1}{c}{$\begin{array}{c}\text { Hubungan } \\
\text { Variable }\end{array}$} & $\begin{array}{c}\text { Original } \\
\text { sample } \\
\text { estimate subsamples }\end{array}$ & $\begin{array}{c}\text { Mean of } \\
\text { samples }\end{array}$ & $\begin{array}{c}\text { Standart } \\
\text { deviation }\end{array}$ & \\
\hline $\begin{array}{l}\text { Knowledge } \rightarrow \\
\text { Development }\end{array}$ & 0.321 & 0.318 & 0.205 & 2.430 \\
$\begin{array}{l}\text { Knowledge } \rightarrow \\
\text { Collaboration }\end{array}$ & 0.221 & 0.218 & 0.155 & 2.127 \\
$\begin{array}{l}\text { Development } \rightarrow \\
\text { Collaboration }\end{array}$ & 0.298 & 0.205 & 0.113 & 2.289 \\
$\begin{array}{l}\text { Development } \rightarrow \\
\text { Performance } \\
\text { Collaboration. } \rightarrow\end{array}$ & 0.227 & 0.272 & 0.179 & 2.060 \\
Performance & 0.496 & 0.479 & 0.145 & 3.426 \\
\hline
\end{tabular}

The results in Table 3 show that the path coefficient from the individual knowledge influencing the work team development has the value of 0.321 and is significant with the $t$-statistic of 2.430 , above 1.96. This research supports a research by Hoof and Deridder (2004) that communication and knowledge sharing within the employee collaboration brings individual effectiveness to create new knowledge. The results in table 3 show that the path coefficient from the influence of individual knowledge bringing impacts to the communication and collaboration within the organization has the value of 0.221 , and is significant with the $t$-statistic of 2.127, higher than 1.96. This research is in accordance to a research by Parris et al. (2005) that the individual efficiency and effecttiveness are achieved when each individual can easily adapt to the new task and work environment, which often called as work personnel flexibility.

The results in Table 3 also show that the path coefficient of the work team development influencing the communication and collaboration in an organization has the value of 0.298 , and is significant with the $t$-statistic of 2.289, above 1.96. This research is supporting the research of work team development that starts from the formation of a team having a combination of people with the right skills and willing to cooperate with others as a work team (Dufrene \& Lehman, 2002). The results of the research in table 3 obtained from the data analysis show that the path coefficient of work team development influencing the company performance has the value of 0.227 , and is significant with the $t$-statistic of 2.060, above 1.96 . This research supports the Dechawatanapaisal (2005) 
research which states training and staff development at ICT Company in Thailand enhancing solid work team and affecting company's performance.

The results of the research in table 3 obtained from the data analysis show that the path coefficient from the employee communication and collaboration in an organization influencing the company performance has the value of 0.496 , and is significant with the $t$-statistic of 3.426, higher than 1.96. This study also supports a research by Emmerik and Sanders (2005) that individual success in working is to build communication and relation with workmates so that they can work efficiently and effectively, with the commitment of every worker in the company.

\section{Conclusion}

Based on the discussion and hypothesis testing, it can be concluded as follows:

a. That individual knowledge on manufacturing companies can provide good work team development due to the sharing knowledge among employees.

b. That individual knowledge on manufacturing companies can improve the work communication and collaboration among the management functions in the company because of the sharing knowledge among employees.

c. That the development of solid work team in the company can improve the work communication and collaboration among the management functions because of the existence of good communication among departments.

d. That the development of a solid work team in the company can improve the company performance, especially in the work effectiveness.

e. That communication and collaboration in the company can improve the company performance especially in the work.

\section{References}

Ardichvili, A., Maurer, A., \& Li, W. (2006). Cultural influence on knowledge sharing through online communities of practice. Journal of Knowledge Management, 10(1), 94-107.

Banerjee, P. (2003). Resources, capability and coordination: Strategic management of information in Indian information sector firms. International Journal of Information Management, 23, 303311.

Basu, V., Hartono, E., Lederer, A. L., \& Sethi, V. (2002). The impact of organizational commit- ment, senior management involvement, and team involvement on strategic information system planning.International Journal of Information Management, 39, 513-524.

Bhatnagar, J. (2008). Managing capabilities for talent engagement and pipeline development. Industrial and Commercial Training, 40(1), 19-28.

Cabrera, E. \& Cabrera, A. (2005). Fostering knowledge sharing through people management practices. International Journal of Human Resources Management, 16(5), 720-735.

Cooper, D. R. \& Schindler, P. S. (2008). Business research methods (10th edition). McGraw-Hill Irwin, New York.

Dechawatanapaisal, D. (2005). HRM as enablers of learning work behaviour: Perspectives from Thai ICT professionals. Research and Practice in Human Resource Management, 13(1), 30-45.

Dufrene \& Lehman. (2002). Building high performance teams. USA: Thomson Learning.

Emmerik, I. J. H. V. \& Sanders, K. (2005). Mismatch in working hours and affective commitment: Differential relationships for distinct employee groups. Journal of Managerial Psychology, 20(8), 712-725.

Harvey, M. \& Napier, N. (2004). The impact of global time on the role of expatriate managers. Research and Practice in Human Resource Management, 12(1), 92-133.

Ho, C. (2007). A framework of the foundation theories underlying the relationship between individuals within a diverse workforce. Research and Practice in Human Resource Management, 15(2), 75-91.

Hoof, B. V. D. \& Deridder, J. A. (2004). Knowledge sharing in context: The influence of organizational commitment, communication climate and CMC use on knowledge sharing. Journal of Knowledge Management, 8(6), 117-130.

Hosie, P., Forster, N., \& Sevastos, P. (2004). The impact of global pressures on the affective wellbeing of Australian managers performance. Research and Practice in Human Resource Management, 12(1), 134-171.

Hu, M. M., Horng, J. S., \& Sun, Y. H. C. (2009). Hospitality teams: Knowledge sharing and service innovation performance. Tourism Management, journal homepage: www.elsevier.com/ locate/tourman.

Johnson, J. (2004). Flexible working: Changing the managers role. Management Decision, 42(6), 721-737. 
Lewis, S., Frenmouw, W. J., Del Ben, K., \& Farr, C. (2001). An investigation of the psychological characteristics of stalkers: Empathy, problemsolving, attachment and borderline personality features. Journal of Forensic Sciences, 46, 8084.

Liao, C. \& Chuang, A. (2004). A multilevel investigation of factor influencing employee service performance and customer outcomes. Academy of Management Journal, 47(1), 41-58.

Magnini, V. P. (2008). Practicing effective knowledge sharing in international hotel joint ventures. International Journal of Hospitality Management, 27, 249-258.

Maley, J. \& Kramar, R. (2007). International Performance Appraisal: Policies, practices and processes in Australian subsidiaries of healthcare MNCs. Research and Practice in Human Resource Management, 15(2), 21-40.

Osterloh, M. \& Frey, B. S. (2000). Motivation, knowledge transfer, and organization forms. Organization Science, 11(5), 538-550.
Parris, M. A., Vickers, M. H., \& Wilkes, L. (2005). Being "stretched" and "squeezed": Organizational flexibility and the middle manager". 4th International Critical Management Studies Conference Cambridge, United Kingdom.

Quang, T. \& Vuong, N. T. (2002). Management styles and organizational effectiveness in Vietnam. Research and Practice in Human Resource Management, 10(2), 36-55.

Spencer, L. M. J. \& Spencer, S. M. (1993) Competence at work: models for superior performance. 1st Edition, Wiley, New York.

Wang, Y. \& Nicholas, S. (2005). Knowledge transfer, knowledge replication, and learning in nonequity alliances: Operating contractual joint ventures in China. Management International Review, 45(1), 99-118.

Wasjo, M. M. \& Farad, S. (2005). Why should I share? Examining social capital and knowledge contribution in electronic networks of practice, MIS Quarterly, 29, 35-57. 